\title{
Skal legene prioritere etter kostnader eller nytte?
}

I dette nummeret av Tidsskriftet viser Melberg \& Bringedal hva et utvalg norske leger tror en magnetisk resonanstomografi (MR) av et kne koster (1). Studien viser at en del leger overvurderte kostnaden, mens i overkant av en tredel kjente riktig nivå. Allmennlegene, som samlet sett antakelig er de største brukerne av denne tjenesten, kjente prisen oftere enn andre leger. Leger har ifølge lov om helsepersonell et ansvar for «å sørge for at helsehjelpen ikke påfører pasienter, helseinstitusjon, trygden eller andre unødvendig tidstap eller utgift» (2). I etiske regler for leger heter det at «en lege skal i sin virksomhet ta tilbørlig hensyn til samfunnets økonomi. Unødige eller overflødig kostbare metoder må ikke anvendes» (3). Dette forutsetter at leger har kunnskap om kostnader ved ulike utredninger og behandlinger.

Melberg \& Bringedal har ikke undersøkt hvordan legene ville ha brukt eventuell kunnskap om kostnad i sin praksis. I en amerikansk pilotstudie av 23 leger i spesialisering fant man at legene valgte rimeligere utredningsalternativ når de kjente kostnadsnivået (4). De ble konfrontert med en hypotetisk sykehistorie der de skulle velge videre undersøkelser. Én gruppe fikk informasjon om kostnadene knyttet til undersøkelsene, mens den andre gruppen ikke fikk slik informasjon. Et ekspertpanel hadde på forhånd vurdert hvilke utredninger som var faglig mest relevante. Gruppen som kjente kostnadene, valgte undersøkelser som var signifikant billigere, men mindre relevante, enn gruppen som ikke kjente kostnadsnivået. Kunnskap om kostnader kan altså endre praksis på måter som ikke nødvendigvis er ønskelige.

Det er ikke bare kostnader som styrer legers prioriteringer. I en norsk studie viste Kristiansen og medarbeidere at trusler fra pasienter og pårørende påvirker legers valg (5). To likt sammensatte grupper leger fikk presentert ulike pasientscenarier der de skulle bestemme videre strategi. Den ene gruppen fikk i tillegg opplyst at det hadde kommet trusler om negativ publisitet i mediene eller om anmeldelse til Fylkeslegen fra pasient eller pårørende. I gruppen som mottok trusler valgte signifikant flere å henvise videre til sykehus/spesialist, selv om dette ikke var medisinsk påkrevd. De som roper høyest får altså mer av ressursene i helsevesenet, antakelig på bekostning av de ressurssvake. Som lege bør man være klar over dette, da det alltid finnes en alternativ anvendelse av ressursene.

For å gjøre prioriteringer i tråd med prioriteringsforskriften (6) trenger leger informasjon om både kostnad og effekt, dvs. kostnadseffektivitet. I en britisk studie ble knepasienter randomisert til to grupper. En gruppe ble henvist til MR av allmennlegen, og en annen gruppe ble henvist til ortoped som gjorde vurderingen av behov for MR. Det kostet omtrent 300 britiske pund mer per pasient når allmennlegen henviste direkte til MR og eventuelt etterpå til ortoped, i forhold til henvisning til ortoped direkte (7). Imidlertid ga denne rutinen 0,05 flere livskvalitetsjusterte leveår (QALY) per pasient. Gruppen som ble henvist direkte til ortoped opplevde lengre ventetid og rapporterte signifikant lavere livskvalitet. Kostnadene per økte livskvalitetsjusterte leveår lå godt under hva som ble regnet som kostnadseffektivt.

I lys av denne studien kan man tenke at fastlegenes henvisning til MR av kne er et kostnadseffektivt tiltak. Så enkelt er det likevel ikke. Nytten av MR kan være mindre enn man skulle tro. Riktignok har
MR stor evne til å avdekke patologi, men ikke alle funn har klinisk relevans. I en amerikansk studie var menisklesjoner påvist ved MR vanligere i en gruppe som ikke hadde knesmerter enn i gruppen som hadde knesmerter (8). Studiens deltakere var over 50 år, og knesmertene skyldtes vanligvis artrose. Selv blant dem med meniskskade var dette funnet gjerne sekundært til artrose. Det var ingen sammenheng mellom MR-funn og smerter/stivhet i gruppen med artrose. Dette vanskeliggjør tolking av MR-funn og reduserer nytten for pasienten. I slike tilfeller vil antakelig det mest nyttige, både for pasient og samfunn, være vanlig røntgenundersøkelse av kneet i første omgang.

Henvisning til MR av kne er bare ett av mange valg der legen må forholde seg til såvel nytte for pasienten som kostnader for samfunnet. For å kunne gjøre gode prioriteringer og opprettholde koordinatorfunksjonen er det nødvendig at leger kjenner kostnadsnivået til undersøkelser og behandlinger. Like viktig er det imidlertid å kjenne deres effekt. I praksis er dette enda vanskeligere. Uten slik kunnskap kan vi ikke vite om tiltakene er kostnadseffektive. Vi tror at et godt tiltak ville være å gi alle leger i spesialisering opplæring i prioritering og kostnadseffektivitet. Det er på dette området som ellers i medisinen: Sunn fornuft trengs, men den er ikke nok. Vi trenger også kunnskap.

\section{Mette Sagsveen}

mette.sagsveen@legeforeningen.no

Guri Rørtveit

guri.rortveit@isf.uib.no

Mette Sagsveen (f. 1978) jobber som medisinsk redaktør i Tidsskrift for Den norske legeforening og er fastlegevikar på Ullevålsveien legesenter og Vettre legekontor.

Guri Rørtveit (f. 1965) er forskningsleder ved Allmennmedisinsk forskningsenhet i Bergen, Uni helse, og professor ved Institutt for samfunnsmedisinske fag. Universitetet i Bergen. Hun er også leder av Tidsskriftets redaksjonskomité.

\section{Oppgitte interessekonflikter: Ingen}

\section{Litteratur}

1. Melberg HO, Bringedal B. Hva tror legene en MR-undersøkelse koster? Tidsskr Nor Legeforen 2010; 130: 598-600.

2. Lov om helsepersonell m.v. Kap. 2, § 6. www.lovdata.no/all/tl-19990702-064002.html\#6 (17.1.2010).

3. Legeforeningen. Etiske regler for leger. Kap 1, § 12. www. legeforeningen.no/id/ $485.1(2.2 .2010)$

4. Rudy DW, Ramsbottom-Lucier M, Griffith CH et al. A pilot study assessing the influences of charge data and group process on diagnostic test ordering by residents. Acad Med 2001; 76: 635-7.

5. Kristiansen IS, Førde $\mathrm{OH}$, Aasland $\mathrm{O}$ et al. Threats from patients and their effects on medical decision making: a cross-sectional, randomised trial. Lancet 2001; 357: 1258-61.

6. Forskrift om prioritering av helsetjenester, rett til nødvendig helsehjelp fra spesialisthelsetjenesten, rett til behandling i utlandet og om klagenemnd (prioriteringsforskriften). Kap. 1, § 2. www.lovdata.no/for/sf/ho/to-200012011208-001.html (25.2.2010).

7. DAMASK (Direct Access to Magnetic Resonance Imaging: Assessment for Suspect Knees) Trial Team. Cost-effectiveness of magnetic resonance imaging of the knee for patients presenting in primary care. Br J Gen Pract 2008; 58: e10-6. doi: 10.3399/bjgp08X342660.

8. Englund M, Guermazi A, Gale D et al. Incidental meniscal findings on knee MRI in middle-aged and elderly persons. N Engl J Med 2008; 359: 1108-15. 